\title{
EFFICIENCY OF PRACTICING WITH MATERIALS USING ICT AND PAPER ONES IN MATHEMATICS
}

Eva Widenská

University of Hradec Kralove

\begin{abstract}
Highlights
- $\quad$ 1. The assessment of efficiency of practicing with materials with or without ICT

- $\quad$ 2. $74 \%$ students chose Interactive computer Auto-Evaluation Test for practicing in mathematics

- $\quad$ 3. Average improvement in mathematics after practicing with was $40 \%$
\end{abstract}

Article type

Full research paper

Article history

Received: April 30, 2014

Received in revised form: June 29, 2014

Accepted: July 2, 2014

Available on-line: July 31, 2014

\section{Keywords}

Auto - Evaluation Test (AET), Information and Communication Technologies (ICT), Pedagogical Experiment, Posttest, Practicing, Pretest

Widenská E. (2014) "Efficiency of Practicing with Materials Using ICT and Paper Ones in Mathematics", Journal on Efficiency and Responsibility in Education and Science, Vol. 7, No. 2, pp. 37-43, online ISSN 1803-1617, printed ISSN 1803-1617, doi: 10.7160/eriesj.2014.070203.

\section{Introduction}

Education in the Czech Republic faces a decline in mathematical literacy. In results of the PISA (Programme for International Student Assessment) in 2012, the Czech Republic results in changes in mathematical literacy in the country from 2003 to 2012 were in 34th level of 39 assessed countries (Palečková, J. 2012). In 2009, the Czech Republic results in changes in the country between 2003 and 2009 were even in last place from 40 evaluated countries (Palečková, J., Tomášek, V. and Basl, J.2009).

The findings in the preliminary research (Widenská, 2011) show that although university students tend to understand the math curriculum and regularly attend training at school, almost do not practice at home.

One of the opportunities which are offered to increase the attractiveness of domestic practice is the use of ICT. In a study from 2009 (Rideout, Foehr, and Roberts, 2010) we can see how huge amount of time young people spend on the computer and on other media. This time could become a great power if we knew how to grasp advantage of its potential.

The trend of our period becomes to help making mathematics more exciting, relevant and challenging to young learners (Oldknow, 2009).

Some students are majorly in nonmathematical fields, some feel some anxiety about math (Bennett and Briggs, 2004).

There is a challenge for us - how to approach the teaching of mathematics to students who have not been (or were only slightly) led to the logical and critical thinking, and are used to learn mathematic ,rote“ without a real understanding of the issues discussed (Friedrich, 2006).

These ideas, trends and reality of our "ICT age" led us to perform a pedagogical experiment:

To offer students practicing material which:

- Is connecting useful and enjoyable - because they like playing games on PC and doing different tests - they can learn at the same time, so it is possible to do autoevaluation test (self-check test) about understanding specified subject of mathematics

- Will be available also in printed form for those who would prefer it, also as auto-evaluation test

- Will not stress with its complicated form - mostly students have much scholarly learning material, but they do not understand it

- Will be interesting and understandable even for those who "feel some anxiety about math"

- Will result with clear answers to essential subjects of specified topic to understand fundamental principles. The aim is mathematical literacy could grow: "Mathematical literacy is defined as: to know, understand and be able to use the appropriate grade curriculum, which is essential" (Hošpesová, 2011:27)

- Will cause a system in fundamental principles

- Will contain auto-evaluation test (self-check test) 
The pedagogical experiment will search:

- Relation between taking part in an experiment and students'study results

- Efficiency of specified combinations of practicing materials in relation to study results and improving results between pretest and posttest

The objective of the paper:

- To determine the effect of practicing on study achievement of university students in mathematics

- The results of students using ICT are compared with the results of those who used either only classical learning support or both

- At the same time, it investigates the effectiveness of particular methods of practicing in various combinations with regard to results achieved in study

Related to these aims we defined these main working hypotheses:

H1: Taking part in the research (i.e. in pretest, practicing and posttest) has an impact to study results of involved students

H2: Practicing mathematics using ICT in teaching is more effective and improves understanding of the topic more than practicing with the study support in the classic form - on paper.

H3: Practicing math with the help of ICT improves more subjective feeling in certainty of answers in the tests and reduces more both tests difficulty rating than with practicing with the study support in the classic form - on paper.

Abbreviations used in this paper can be found in Table 1.

\section{Materials and Methods}

\section{Previous research}

\section{Preliminary research}

Preliminary research was carried out in the academic year 201011 (Widenská, 2011) at the Faculty of Chemical Technology, University of Pardubice. Unsatisfactory level of students admitted to study in basic mathematical knowledge and skills has been proven.

Also there was shown large knowledge distance among students coming from different types of schools.

Despite the relatively large effort to regular attendance and understanding of the curriculum during seminars taught math, students were practicing at home very little.

Based on these findings there were formulated the following research questions:

Will be increased understanding mathematics through applications of auto - evaluation test (AET)?

Will be the effectiveness of using the interactive computer AET (PC AET) higher than practicing with AET in printed form?

Will we be successful in motivation of students to practice the tested subject after the preliminary research showed that a large part of the seminar participants almost didn't practice at home?

A pilot study

A pilot study with 620 included students in the full-time form of study, in their first semester, was realized in academic year 201112. Its results were published: (Widenská a), 2012), (Widenská b), 2012), (Widenská c), 2012).

Due to the results and commentaries in ICTE conference, Ph.D. students'section, there were made several revisions and changes the research to be continued in academic year 2012-13.

\section{Plan of research}

\section{Time limitation}

The research took place in the winter semester of 2012 -13 and in the subsequent examination period.

Students met the first information about the ongoing research in the eighth week of the semester. In the tenth week of the semester the students were subjected to a pretest. In the same week, just after the pretest, the students received practicing materials and in the twelfth week were subjected to a posttest. Both tests were conceived in relation to practicing material.

During the examination period, students were tested in writing, they had to solve several problems in the selected subjects of the entire semester, some of tasks here were chosen with regard to the AET. The last day of testing was 28th May 2013.

\section{Data Collection}

Students who took part in the research filled in the pretest and the posttest. Each test was rated from 0 to 20 points.

There were recorded each student's:

- $\quad$ pretest results (IN)

- $\quad$ posttest results (OUT)

- $\quad$ kind of used practicing material

- $\quad$ subjective feeling in certainty of answers in the tests

- both tests difficulty rating

- results of the exam (EXAM)

- information about continuing in study after the first semester (CONT)

Information about subjective feeling in certainty of answers in the tests and both tests difficulty rating connected with working hypothesis $H 3$ will be statistically processed in the dissertation.

Concepts

The practicing material included two kinds of topics:

- refreshing and summarizing some of the basic knowledge acquired during high school, necessary for understanding the principle of differentiation of functions of one variable

- for most students new topic Fundamentals of differential calculus of functions of one variable (further mentioned as a derivative)

Practicing materials were intended to lead illustratively and schematically the student to repeat, respectively understand the concepts and relations among them. This is not only a formal knowledge of definitions, but their active application in examples, where it is recognized understanding of the topic.

\section{The course of the experiment}

\section{Information for students}

The students met the first information about ongoing research in the eighth week of the winter semester 2012-13 during lectures in all study groups. The information contained schedule, explanation, conditions and benefits to students for participation in the research.

Students were motivated to practice math as follow:

- They had opportunity to get up to 20 points for the output test (posttest). These points will be added to the exam test (there is a maximum of 100 points); entire posttest contained part of the topics discussed in the course Mathematics 1.

- They could check answering in the AET questions of a similar type like in an exam. 
The tasks for the students were:

- To take part in the entrance test (pretest) in the 10th week of the semester. This pretest did not generate any point advantage for students, but its completion was a condition for participation in the output test.

- To practice using the practicising materials accessible after passing the pretest. Students had minimally 12 days for practicing.

- To take part in the output test (posttest) in 12th week. The results of this test had been announced to students before the start of their exam period.

Entrance test (pretest)

Pretest was assigned to show the input level of specified knowledge.

In its first half it contained repeated basic concepts (10 questions for 10 points), in its second half it contained topic derivative (10 questions for 10 points).

Both the pretest and the posttest were designed to verify understanding the topic - all of the key knowledge and skills listed in practicing material were chosen for them.

Pretests were used for later comparison with the results of the posttest.

377 students participated in the pretest.

\section{Practicing}

In addition to lectures and seminars (ongoing for the topic till 9th week of the semester) students received practicing material with its content targeted directly to the theme of the posttest.

The content of practicing material was determined both considering the results of the pretest in previous research in 2011-2012 and considering the newly acquired knowledge and skills base showing understanding of calculus.

Types of practicing materials: the theme was prepared in these types:

- $\quad$ Summary (S) - summarizing survey part - repetition and explanation

- Auto-evaluation tests (AET). AET aimed to verify understanding of the matter in the form of answers to questions (as in the examination test), but there were given the correct answers.

AET had two forms, both were with the same tasks. Students chose responses (multiple-choice), answered open questions with extensive or brief answers.

- "Paper" (PA) AET could be either printed on paper or worked with by watching on a computer monitor in a form of presentation. It was not interactive; for checking the correct answers there were results at the end of the test. The sequence of questions was logically arranged from the easiest task to the most difficult one.

- In "Interactive computer" (PC) AET it was necessary to click the correct answer $(1$ task $=$ screen $)$. Another question was provided to the student after marking the correct answer; in the case of wrong answer it could be marked again.

PC AET was made both in sequential version - still the same, logically arranged sequence of questions as in paper form; and random version - different order of questions generated by a computer. The advantage of the sequential test is gradually increasing demands on the understanding and application of concepts, the disadvantage is the possibility of remembering the order of answers in the test. This disadvantage is eliminated in the test with random sequence of questions, but it is more suited for students who passed successfully through the sequential version of the test.

PC AET was created in the author system Macromedia Authorware-the University owns its licence. Macromedia Authorware is one of the most comprehensive authoring tools for creating e-learning applications, popularly educational e-books, interactive training courses. Environmental control program is simple and intuitive. It is possible to import a PowerPoint presentation into it. The students in the research obtained .exe files with PC AET so they were able to work with no special software on their computers.

Students had the opportunity to choose any method or combination of practicing. They mentioned used methods in the questionnaire at the end of the posttest.

Because we expected students to use also different type of practicing material for preparation to the posttest (such as notes from their high school), in the questionnaire there was possibility to mark "another practicing material".

\section{Output test (posttest)}

Posttest showed advance of students in specified skills after practicing.

The concept of the posttest was the same as the pretest, only numeric values were different.

Posttest was attended by 343 students.

\section{Results}

\begin{tabular}{|l|l|}
\hline Abbreviation & Meaning \\
\hline AET & Auto-Evaluation Test \\
\hline ALL & $\begin{array}{l}\text { Amount of students who used all given practicing } \\
\text { materials }\end{array}$ \\
\hline CONT & $\begin{array}{l}\text { Amount of students who continued in studying after } \\
1 \text { semester }\end{array}$ \\
\hline CONT\% & $\begin{array}{l}\text { Amount of students who continued in studying after 1 } \\
\text { semester in percents }\end{array}$ \\
\hline EXAM & Amount of students who passed the exam \\
\hline EXAM\% & Amount of students who passed the exam in percents \\
\hline IN & Amount of points received in pretest (IN-test) \\
\hline NONE & $\begin{array}{l}\text { Amount of students who used no given practicing } \\
\text { materials }\end{array}$ \\
\hline nonCONT & $\begin{array}{l}\text { Amount of students who did not continue in studying } \\
\text { after 1 semester }\end{array}$ \\
\hline nonEXAM & Amount of students who did not pass the exam \\
\hline OUT & Amount of points received in posttest (OUT-test) \\
\hline PA & $\begin{array}{l}\text { Amount of students who used practicing material: } \\
\text { just Paper AET }\end{array}$ \\
\hline PAAET & Practicing material: Paper AET \\
\hline PA+ & $\begin{array}{l}\text { Amount of students who used practicing material: } \\
\text { Paper AET }\end{array}$ \\
\hline PAPC & $\begin{array}{l}\text { Amount of students who used practicing material: } \\
\text { just Paper AET and Interactive Computer AET }\end{array}$ \\
\hline PAPC+ & $\begin{array}{l}\text { Amount of students who used practicing material: } \\
\text { just interactive computer AET }\end{array}$ \\
\hline PC & $\begin{array}{l}\text { Amount of students who used practicing material: } \\
\text { Interactive Computer AET }\end{array}$ \\
\hline PC AET + & Practicing material: \\
\hline
\end{tabular}


Widenska E. - ERIES Journal vol. 7 no. 2

\begin{tabular}{|l|l|}
\hline Abbreviation & Meaning \\
\hline PM & Practicing material \\
\hline REG & $\begin{array}{l}\text { Amount of all students registered in subject of } \\
\text { Mathematics 1 }\end{array}$ \\
\hline S & $\begin{array}{l}\text { Amount of students who used practicing material: } \\
\text { just Summary }\end{array}$ \\
\hline S+ & $\begin{array}{l}\text { Amount of students who used practicing material: } \\
\text { Summary }\end{array}$ \\
\hline SPA & $\begin{array}{l}\text { Amount of students who used practicing material: } \\
\text { just Summary and Paper AET }\end{array}$ \\
\hline SPA+ & $\begin{array}{l}\text { Amount of students who used practicing material: } \\
\text { Summary and Paper AET }\end{array}$ \\
\hline SPC & $\begin{array}{l}\text { Amount of students who used practicing material: } \\
\text { just Summary and Interactive Computer AET }\end{array}$ \\
\hline SPC+ & $\begin{array}{l}\text { Amount of students who used practicing material: } \\
\text { Summary and Interactive Computer AET }\end{array}$ \\
\hline Summary & $\begin{array}{l}\text { Practicing material: summarizing survey part - } \\
\text { repetition and explanation }\end{array}$ \\
\hline Used & $\begin{array}{l}\text { Amount of students who used specified practicing } \\
\text { material }\end{array}$ \\
\hline Used \% & $\begin{array}{l}\text { Amount of students who used specified practicing } \\
\text { material as percentage of total }\end{array}$ \\
\hline WGroup & Amount of students in specific whole group \\
\hline WGroup \% & $\begin{array}{l}\text { Amount of students in specific whole group as } \\
\text { percentage of total }\end{array}$ \\
\hline Wrote IN & Amount of students who wrote only pretest (IN-test) \\
\hline Wrote IN+ & Amount of students who wrote pretest (IN-test) \\
\hline $\begin{array}{l}\text { Wrote } \\
\text { IN+OUT }\end{array}$ & $\begin{array}{l}\text { Amount of students who wrote pretest (IN-test) and } \\
\text { posttest (OUT-test) }\end{array}$ \\
\hline Wrote & $\begin{array}{l}\text { Amount of students who wrote neither pretest (IN- } \\
\text { test), nor posttest (OUT-test) }\end{array}$ \\
NONE & Chi-square test of independence \\
\hline$\chi^{2}$ & andable \\
\hline
\end{tabular}

Table 1: Abbreviations

\begin{tabular}{|l|c|c|c|c|}
\hline \multicolumn{1}{|c|}{ Group } & REG & Wrote NONE & Wrote IN & $\begin{array}{c}\text { Wrote } \\
\text { IN+OUT }\end{array}$ \\
\hline WGroup & 559 & 182 & 34 & 343 \\
\hline EXAM & 310 & 15 & 10 & 285 \\
\hline CONT & 338 & 31 & 14 & 293 \\
\hline
\end{tabular}

Table 2: Amounts of students in different phases of the pedagogical experiment

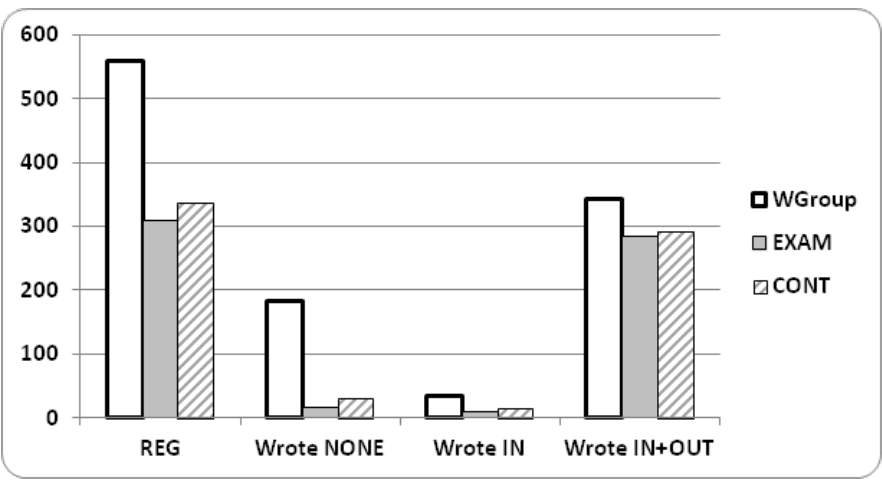

Figure 1: Graph of amounts of students in different phases of the pedagogical experiment

\begin{tabular}{|c|c|c|c|c|}
\hline Group & REG & Wrote NONE & Wrote IN & $\begin{array}{c}\text { Wrote } \\
\text { IN+OUT }\end{array}$ \\
\hline WGroup \% & 100 & 100 & 100 & 100 \\
\hline EXAM \% & 55 & 8 & 29 & 83 \\
\hline CONT \% & 60 & 17 & 41 & 85 \\
\hline
\end{tabular}

Table 3: Amounts of students in different phases of the pedagogical experiment in percent of each group

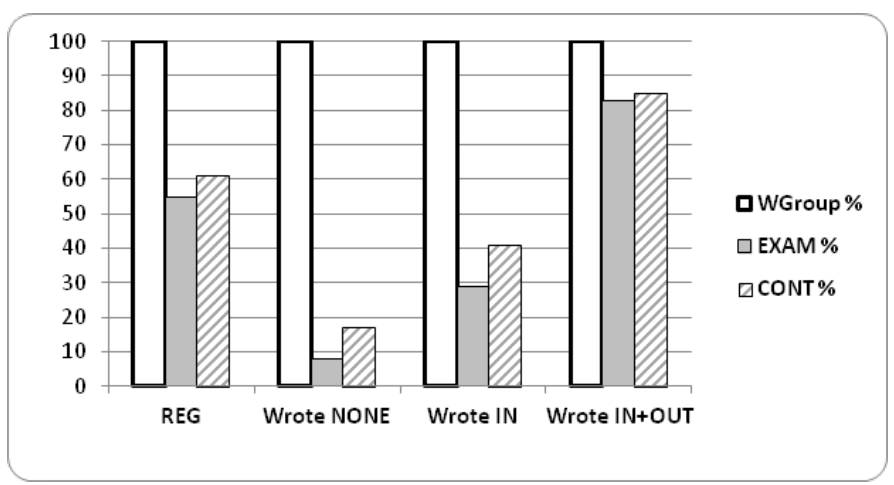

Figure 2: Graph of amounts of students in different phases of the pedagogical experiment in percent of each group

\section{Taking part in the experiment}

Table 2 with Figure 1 shows amounts of students who took part in specified phases of the experiment, Table 3 and Figure 2 shows the same in percent of each group.

At the beginning of winter semester 2012-13 there were registered 559 (the group "REG") students in the subject of Mathematics 1.

343 students (61\% from the group "REG") participated in posttest. This number highly overcame our expectation. In the pilot study 2011-12 306 students from 620 passed through the whole experiment, that was $49 \%$. That means in 2012-13 we had 37 students in the group "Wrote IN+OUT" more than a year ago.

$310(55 \%)$ of the group "REG" successfully passed the exam and $338(60 \%)$ continued in their studies after the first semester. 182 students did not write any test, $15(8 \%)$ of them successfully passed the exam and $31(17 \%)$ continued in their studies after the first semester.

34 students wrote only pretest, $10(29 \%)$ of them successfully passed the exam and $14(41 \%)$ continued in their studies after the first semester.

343 students wrote both pretest and posttest, 285 (83\%) of them successfully passed the exam and 293 (85\%) continued in their studies after the first semester.

With data from Table 2 we tested two kinds of hypotheses. Chisquare test of independence $\mathbf{X}^{2}$ is used to verify them; the tables with the data are Tables 5 and 6 :

1. Null hypothesis $H_{O E X}$

Number of students who will be successful in examination with participation in pretest and posttest will be the same as without participation in these tests.

Alternative hypothesis $\mathrm{H}_{\mathrm{AEX}}$ 
Number of students who will be successful in examination with participation in pretest and posttest will be different from the group of students who did not participate in these tests.

\section{Null hypothesis $\mathrm{H}_{\mathrm{OCON}}$}

Number of students who will continue their studies after the first semester with participation in pretest and posttest will be the same as without participation in these tests.

Alternative hypothesis $H_{A C O N}$ :

Number of students who will continue their studies after the first semester with participation in pretest and posttest will be different from the group of students who did not participate in these tests.

Both these kinds of hypotheses were tested with the chi-square test of independence $\chi^{2}$ (Chráska, 2007) defined in (1). The meaning of letters in the equation is seen in the schema of 4-field table (Table 4).

\begin{tabular}{|c|c|c|c|}
\hline & $\boldsymbol{\alpha}$ & non $\boldsymbol{\alpha}$ & $\sum$ \\
\hline $\boldsymbol{\beta}$ & $\mathrm{a}$ & $\mathrm{b}$ & $\mathrm{a}+\mathrm{b}$ \\
\hline $\boldsymbol{n o n} \boldsymbol{\beta}$ & $\mathrm{c}$ & $\mathrm{d}$ & $\mathrm{c}+\mathrm{d}$ \\
\hline$\sum$ & $\mathrm{a}+\mathrm{c}$ & $\mathrm{b}+\mathrm{d}$ & $\mathrm{n}$ \\
\hline
\end{tabular}

Table 4: Schema of 4-field table

$$
x^{2}=\mathrm{n} \cdot \frac{(a d-b c)^{2}}{(a+b) \cdot(a+c) \cdot(b+d) \cdot(c+d)}
$$

\begin{tabular}{|c|c|c|c|}
\hline & EXAM & nonEXAM & $\sum$ \\
\hline $\begin{array}{c}\text { Wrote } \\
\text { NONE }\end{array}$ & 15 & 167 & 182 \\
\hline $\begin{array}{c}\text { Wrote } \\
\text { IN+OUT }\end{array}$ & 285 & 58 & 343 \\
\hline$\sum$ & 300 & 225 & 525 \\
\hline
\end{tabular}

Table 5: 4-field table for chi-square test of independence $\chi^{2}$ - successfulness of students in passing the exam (for testing $\boldsymbol{H}_{O E X}$ and $\boldsymbol{H}_{A E X}$ )

\begin{tabular}{|c|c|c|c|}
\hline & CONT & nonCONT & $\sum$ \\
\hline $\begin{array}{c}\text { Wrote } \\
\text { NONE }\end{array}$ & 31 & 151 & 182 \\
\hline $\begin{array}{c}\text { Wrote } \\
\text { IN+OUT }\end{array}$ & 293 & 50 & 343 \\
\hline$\sum$ & 324 & 201 & 525 \\
\hline
\end{tabular}

Table 6: 4-field table for chi-square test of independence $\chi^{2}$ - continuing in studies after the first semester (for testing $\boldsymbol{H}_{O C O N}$ and $\boldsymbol{H}_{A C O N}$ )

\begin{tabular}{|c|c|c|}
\hline Tested hypothesis & Default values & Tested criterion $\boldsymbol{\chi}^{\mathbf{2}}$ \\
\cline { 1 - 2 }$H_{O E X}$ & Table 4 & 272.012 \\
\cline { 1 - 2 }$H_{A E X}$ & Table 5 & \\
\cline { 1 - 2 }$H_{O C O N}$ & & 235.378 \\
\cline { 1 - 2 }$H_{A C O N}$ & & \\
\hline
\end{tabular}

Table 7: The results of tested criterion $\chi^{2}$ and default tables for tested hypotheses

In Tables 5 and 6 we see the values emerged from Table 2, with calculation of test criterion we tested the hypotheses. During testing, we compared the resulting values of the test criterion with its critical value. Critical tabulated value $\chi^{2}$ for 1 degree of freedom and level of significance $5 \%$ is 3.841 .

Result for $H_{A E X}$ is 272.012 , for $H_{A C O N}$ it is 235.378 , they are seen in Table 7.

Both results are highly more than the critical value. That means we can state:

1. We reject null hypothesis $H_{O E X}$ and accept hypothesis $H_{A E X}$ The results are statistically significant.

2. We reject null hypothesis $H_{O C O N}$ and accept hypothesis $H_{A C O N}$. The results are statistically significant.

\section{Using of practicing materials}

Furthermore we can see results of using different combinations of practicing materials (PM). Students could choose any type of offered PM and their combinations. As we expected, some students used also different types - they announced it in a posttest questionnaire. They were 22 and we did not include them into the statistics about effectiveness of using given materials. This means we continued the research with the group of 321 students. In this paper we present (also shown in Table 8 with Figure 3 and Table 9 with Figure 4):

Amounts of students using each combination of PM

In Table 8 with Figure 3 we can observe three most frequent used combinations:

- $239(74 \%)$ students used Interactive computer autoevaluation test (PC AET) or PC AET plus some other PM.

- PC AET was a favourite PM - mostly in combination with other PM, but also in use when students chose only one PM.

- 171 (53 \%) students used Summary (S) or S plus some other PM.

- 115 (36\%) students used S and PC or S, PC plus Paper AET (PA AET).

Relation between using specified combination of $P M$ and successfulness in exam

When we see (Table 9 with Figure 4) percentage successfulness in exam in each combination of PM, we see these three leading PM:

- PAAET with $92 \%$ successfulness in exam

- PA and PC AET with $87 \%$ successfulness in exam

- $\quad$ S and PC AET with $86 \%$ successfulness in exam

Relation between using specified combination of PM and continuing in studies after the first semester 
In observing (Table 9 with Figure 4) continuing in studies after the first semester in relation to used combination of PM, we see these three main PM:

- S with $94 \%$ of students continuing in studies after the first semester

- $\quad$ All PM (this means S, PA and PC AET = ALL) with $90 \%$ of students continuing in studies after the first semester

- $\mathrm{SPA}+$ with $89 \%$ of students continuing in studies after the first semester

\begin{tabular}{|l|c|c|c|}
\cline { 2 - 4 } \multicolumn{1}{c|}{} & Used & EXAM & CONT \\
\hline $\mathrm{S}$ & 16 & 11 & 15 \\
\hline $\mathrm{PA}$ & 13 & 12 & 11 \\
\hline $\mathrm{PC}$ & 101 & 84 & 87 \\
\hline $\mathrm{S}+$ & 171 & 142 & 151 \\
\hline $\mathrm{PA}+$ & 106 & 90 & 92 \\
\hline PC+ & 239 & 202 & 206 \\
\hline SPA & 40 & 33 & 35 \\
\hline SPA + & 70 & 58 & 62 \\
\hline SPC & 85 & 73 & 74 \\
\hline SPC + & 115 & 98 & 101 \\
\hline PAPC & 23 & 20 & 18 \\
\hline PAPC + & 53 & 45 & 45 \\
\hline ALL & 30 & 25 & 27 \\
\hline NONE & 13 & 11 & 11 \\
\hline
\end{tabular}

Table 8: Amounts of students using different combinations of practicing materials and their success in exam and continuing in studies after the first semester

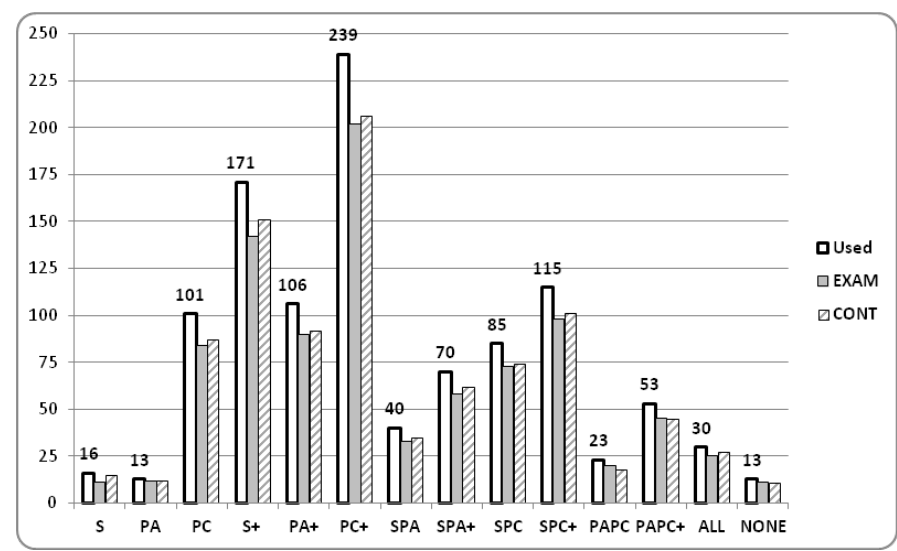

Figure 3: Graph of amounts of students using different combinations of practicing materials and their success in exam and continuing in studies after the first semester

\begin{tabular}{|c|c|c|c|}
\cline { 2 - 4 } \multicolumn{1}{c|}{} & Used $\%$ & EXAM $\%$ & CONT\% \\
\hline $\mathrm{S}$ & 100 & 69 & 94 \\
\hline $\mathrm{PA}$ & 100 & 92 & 85 \\
\hline $\mathrm{PC}$ & 100 & 83 & 86 \\
\hline $\mathrm{S}+$ & 100 & 83 & 88 \\
\hline $\mathrm{PA}+$ & 100 & 85 & 87 \\
\hline $\mathrm{PC}+$ & 100 & 85 & 86 \\
\hline $\mathrm{SPA}$ & 100 & 83 & 88 \\
\hline $\mathrm{SPA}+$ & 100 & 83 & 89 \\
\hline $\mathrm{SPC}$ & 100 & 86 & 87 \\
\hline $\mathrm{SPC}+$ & 100 & 85 & 88 \\
\hline
\end{tabular}

\begin{tabular}{|c|c|c|c|}
\cline { 2 - 4 } \multicolumn{1}{c|}{} & Used \% & EXAM\% & CONT\% \\
\hline PAPC & 100 & 87 & 78 \\
\hline PAPC+ & 100 & 85 & 85 \\
\hline ALL & 100 & 83 & 90 \\
\hline NONE & 100 & 85 & 85 \\
\hline
\end{tabular}

Table 9: Amounts of students using different combinations of practicing materials in percent of each combination

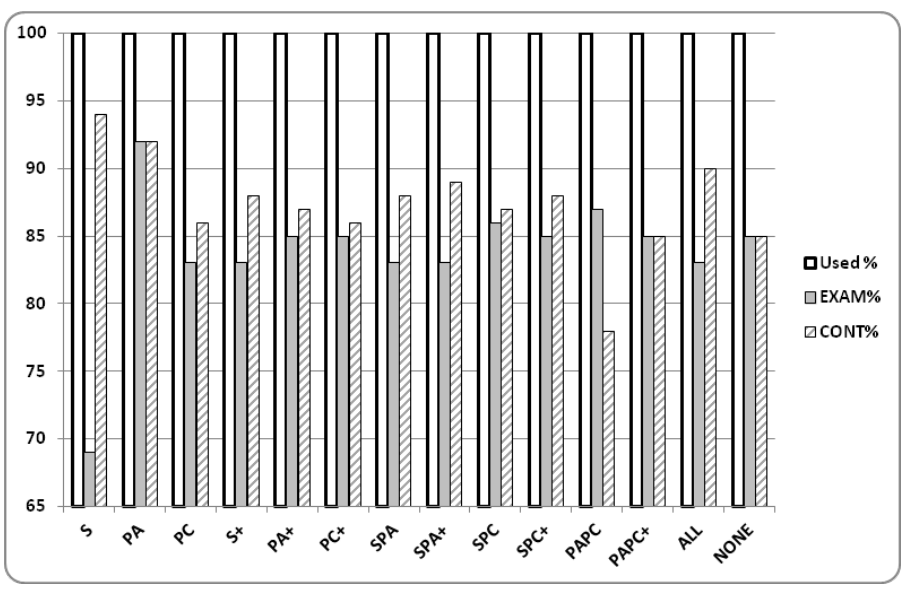

Figure 4: Graph of amounts of students using different combinations of practicing materials in percents of each combination

The results of the research showed the importance of involving students in research itself. Participation in the pretest greatly increased the success rate for the exam and the percentage of students who continued their studies after the first semester. This suggests the participation of all interested students to study and awareness of ongoing activities. Given the choice of PC AET was voluntary, and students who chose this kind of practice, were even several times better than in the beginning (the best improving was $267 \%$ ). The computer practical exercises had great educational significance. At the same time, however, the practice of traditional paper form had for students a positive effect on the outcome of the final test as well. Any method of practicing in our case had a positive impact on students' knowledge.

\section{Discussion}

Input and output tests with questionnaires were developed for the specific needs of students at the Faculty of Chemical Technology, they were not standardized. The requirements regarding the level of mathematics may be different at different schools and they could hardly be compared with other similar studies in terms of quantitative data.

However, an investigation of this method with respect to the size of the sample is of great importance. This confirms the importance of practicing with any of techniques and practicing with materials with ICT played an important role for those students who chose this method.

The best result with $92 \%$ successfulness in exam was with students who used PA AET. We can ask why just this kind of practicing had the best result. With careful using PA AET the study result can be very good. But the number of these students was 13 and it is statistically very small sample of the whole group Wrote IN+OUT of 343 people - less than $4 \%$. In the questionnaire in the posttest some students mentioned they had preferred this kind of practicing, it had been the best for them.

We would suppose the students using all practicing materials 
will have the best results. The percentage of success in the exam respectively in continuing in study is not the highest, but is very high $(83 \%$, resp. $90 \%)$. So students had very good results - on the other hand using all kinds of materials need not mean using all of them carefully.

Special group of students are those who mentioned using no practicing material. They were 13 . This is also a very small statistical sample - but suprisingly they have very good result in passing the exam and continuing in study (85\%). 11 of these students passed successfully the exam and continued studying after the first semester. Their average pretest result was 17.0 points. This number is highly greater than average pretest result of the Wrote IN group (it was 12 points). During personal asking some of them about no practicing they answered they had had no need to practice.

Those 2 students, who did not practice and did not pass successfully the exam and did not continue in their studies after the first semester, had their average pretest result 9.5 points. They answered they had not managed practicing.

\section{Conclusion}

We found the motivation for students to be involved in the pedagogical experiment was more successful than in the pilot study in 2011-12. $12 \%$ more students of REG took part in the whole experiment.

We proved as statistically significant relation between taking part in the experiment and successful passing exam, respectively continuing in study after the first semester.

High percentage of students $(74 \%)$ used for their practicing Interactive Computer Auto-Evaluation test.

Data from the experiment are intended to use in another statistical research. We will search relation among using different types of PM and progress between pretest and posttest. Now we can present average improvement in group "Wrote IN+OUT" between these tests from 12 points in pretest to 17 points in the posttest $(40 \%) .137$ students $(42 \%)$ improved these results more than $50 \%$.

The students, who had excellent results already in the pretest, e.g. 19-20 points, could have their posttest result maximally 5 $\%$ better. This group of students will be investigated separately in the dissertation.

\section{References}

Bennett, J., Briggs, W. (2004) Using and Understanding Mathematics, A Quantitative Reasoning Aproach, Boston: Addison Wessley.

Friedrich, V. (2006) 'Lze matematiku učit moderně, zajímavě a distančně?', Proceedings of the 4th Conference on Distance Education in the Czech Republic - Present and Future, Ostrava. Hošpesová, A. (2011) Matematická gramotnost a vyučování matematice, České Budějovice: Jihočeská univerzita, Pedagogická fakulta.

Chráska, M. (2007) Metody pedagogického výzkumu: základy kvantitativního výzkumu, Prague: Grada Publishing.

Oldknow, A. (2009) 'ICT bringing mathematics to life and life to mathematics', The Electronic Journal of Mathematics and Technology, vol. 3, no 2,pp. 137-148.
Palečková, J., Tomášek, V. and Basl, J. (2009) Hlavni zjištění výzkumu PISA 2009, umíme ještě číst?, [Online], Available:

http://img2.ct24.cz/multimedia/documents/23/2281/228041.pdf [24 Apr 2014].

Palečková, J. (2012) Hlavní zjištěni PISA 2012, Seminář k PISA 2012, [Online], Available:

http://www.pisa2012.cz/?a=ke_stazeni [24 Apr 2014].

Rideout, V. J., Foehr, U. G. and Roberts, D. F. (2010) 'Generation M2: Media in the Lives of 8-18year-Olds', [Online], Available:

$\mathrm{http}$ //kff.org/other/poll-finding/report-generation-m2-mediain-the-lives/_[24 Apr 2014].

Widenská, E. (2011) 'Vstupní informace pro zjišt’ování změny $\mathrm{v}$ dovednostech z matematiky', Proceedings of the Conference DiTech'11, Hradec Králové.

Widenská E., a) (2012) 'Průzkum efektivity využití procvičovacího testu v matematice s využitím ICT vzhledem ke klasické studijní opoře (tištěnému materiálu)', Proceedings of the Conference DiTech'12, Hradec Králové.

Widenská, E. b) (2012) 'Průzkum efektivity využití procvičovacího testu v matematice s uplatněním ICT vzhledem $\mathrm{k}$ testu $\mathrm{v}$ klasické (tištěné) podobě', Proceedings of the Conference Information and Communication Technologies in Education, Ph.D. students'section, Ostrava.

Widenská, E. c) (2012), 'Research of effectiveness of autoevaluation test in Mathematics using ICT in relation to classical study support (printed material)', Proceedings of the Conference on Odborová didaktika - interdisciplinárny dialóg, Levoča, Slovakia, pp. 288-297. 